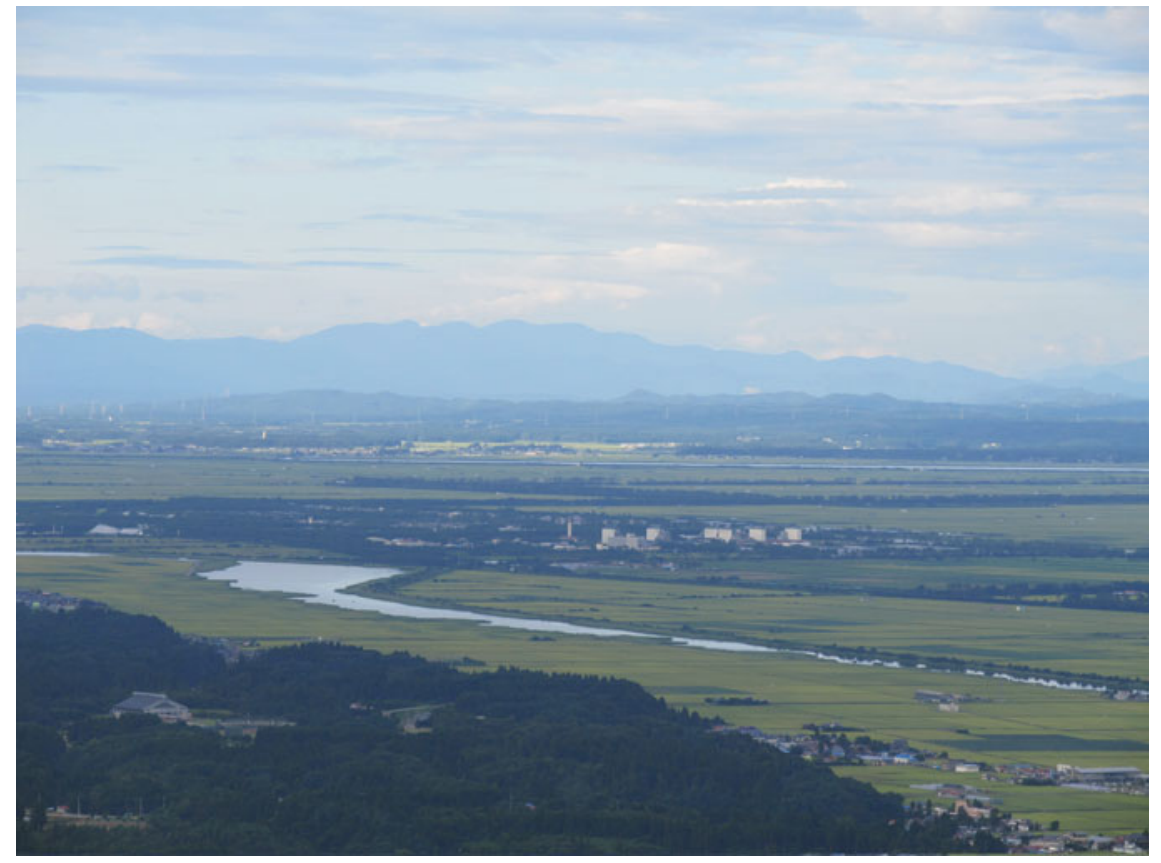

The Hachirogata Region and the Hachirogata Central Polder (Photo by Yasunori Kitao) 


\title{
Chapter 10 \\ Reassessing Heritage: Contradiction \\ and Discrepancy Between Fishery \\ and Agriculture in Planning \\ the Hachirogata Polder and Its \\ Surrounding Lagoon in Mid-Twentieth \\ Century Japan
}

\section{Yasunori Kitao}

\begin{abstract}
The Hachirogata central polder in Akita Prefecture in Japan is an important example of a completely planned and constructed agricultural production landscape and also of an industrial heritage landscape built in the context of the myth of modernism and large-scale planning intervention. The land was reclaimed from the Hachirogata lagoon in the middle of the twentieth century with the help of Dutch engineers. Today, the polder is one of the most productive landscapes in Japan for growing rice. For centuries, the fishery was the main industry of the lagoon. But the government was interested in developing agriculture by turning the lagoon into agricultural land, and it did not initially consider fishermen's rights or the traditional lifestyle and heritage of the region in its planning. This chapter explores the planning of the land reclamation from about 1930 to the late 1950s. Drawing on articles in local newspapers and on official planning documents, it explores the conflicting interests and heated debates between the central government, the prefecture office, local municipalities, and local people regarding agriculture and fishing in local history. It contributes insights on food production, environmental issues, and local traditional industries to both heritage debates and the planning of future industrial heritage landscapes.
\end{abstract}

Keywords Polder $\cdot$ Regional development $\cdot$ Regional planning $\cdot$ Fishery Agriculture $\cdot$ Brackish water

\footnotetext{
Y. Kitao $(\bowtie)$

Kyoto Women's University, Kyoto, Japan

e-mail: kitaoy@kyoto-wu.ac.jp 


\section{Introduction}

The Hachirogata central polder, located in Akita prefecture on the northern end of the Japanese main island, Honshu, is well known for its large-scale, environmentally conscious rice production (General Affairs and Planning Section of the Ogata Mura Village Office 2011). Ogata Mura, the only rural village in the polder, is known as an advanced case of local autonomy (Miyata et al. 2012). The Hachirogata polder is also an important example of a completely planned and constructed agricultural production landscape in Japan. The construction of the polder is celebrated as a great achievement: the polder museum in Ogata Mura presents it as a success of modern large-scale agriculture in line with the most advanced international practices, and a symbol of Japan's engineering heritage; and foreign literature holds it up as an example of government intervention aimed at creating an ideal society, and the buildings and structures that serve it (Van den Heuvel et al. 2008).

These celebrations focus only on the rural development planning phase in the 1960s when city planners, architects, and other specialists collaborated to build a new village on the polder (Kitao 2008). Such a writing of the polder's heritage effectively constructs a rather limited assessment. It ignores the heritage of the water area that remains of the Hachirogata lagoon, formed at the same time as the Hachirogata central polder.

This paper assesses the remaining lake as part of the industrial heritage of the area. The polder heritage is effectively composed of two different historic practices: agriculture on the newly created land; and fishery in the remaining lake. The relation between the lake and the polder is Yin and Yang, balanced, and always together. This chapter, therefore, explores the hidden history of the water landscape in order to fully understand the development of the entire lagoon area. Then, it will be possible to evaluate the central polder as a part of the modern industrial heritage of the region.

The Hachirogata polder was reclaimed from the Hachirogata lagoon in the middle of the twentieth century with the help of Dutch engineers. Japan has a history of modern land reclamation dating to the beginning of the twentieth century, which coincided with an increased interest in modern polder projects in the Netherlands. As early as 1914, the Ministry of Agriculture and Commerce in Japan published a report, The Great Planning of Expanding Arable Lands in the Netherlands, outlining the Zuider Zee project, a large man-made system of land reclamation, dams, and dykes; it also analyzed the Dutch Government's policy of providing fishermen with funding for bigger boats so that they could fish in the North Sea rather than the Zuider Zee. Shortly thereafter, in 1916, the Fisheries Experiment Station of Akita Prefecture began a detailed investigation of the fishery resources of the Hachirogata lagoon and the agricultural implications of creating the Hachirogata polder. Despite extensive studies and discussions of the lagoon and its historical significance, the research did not result in a plan that satisfied all parties. As the records make clear, fishermen strongly opposed the impoldering project. (In this text, "fishermen" refers to collectives such as fishermen's cooperatives or fishermen's informal groups). 


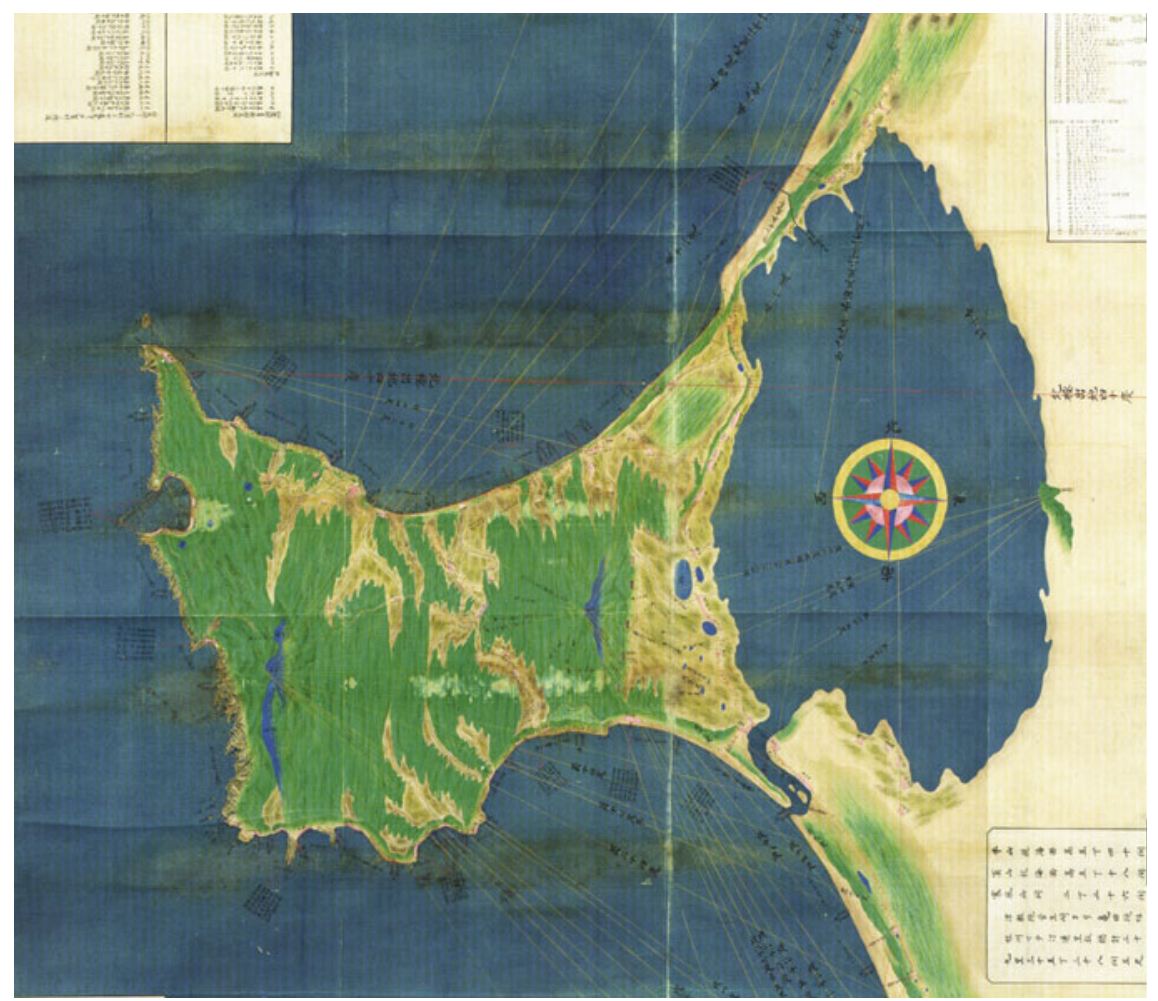

Fig. 1 An old map of the Hachirogata lagoon. This map was made in the nineteenth century for the national defense policy at that period. The " $*$ " mark indicates that the lagoon is located at a longitude of $140^{\circ}$ east and a latitude of $40^{\circ}$ north. Source Akita Prefectural Library; released under a Creative Commons Attribution-NonCommercial-NoDerivatives 4.0 International License

This chapter explores the history of competing visions in the planning process for the Hachirogata lagoon, particularly between creating a landscape supporting fishing and one supporting agriculture (The Fisheries Experiment Station of Akita Prefecture 1916). (Figures 1, 2 and 3). We draw on local newspapers, project reports, and related literature to illuminate the hopes and worries of the different stakeholders, starting in the early 1930s, when the wartime regime came to power, and ending in the late 1950s, when the conflicts were resolved and the construction work was launched.

\section{Local Fishery and Governmental Policy}

The Hachirogata lagoon (called Hachiroko lake in the past: "gata" means "lagoon," and "ko" means "lake") was a brackish body of water located about $20 \mathrm{~km}$ north of Akita city, at a latitude of $40^{\circ}$ north and a longitude of $140^{\circ}$ east. Before the 


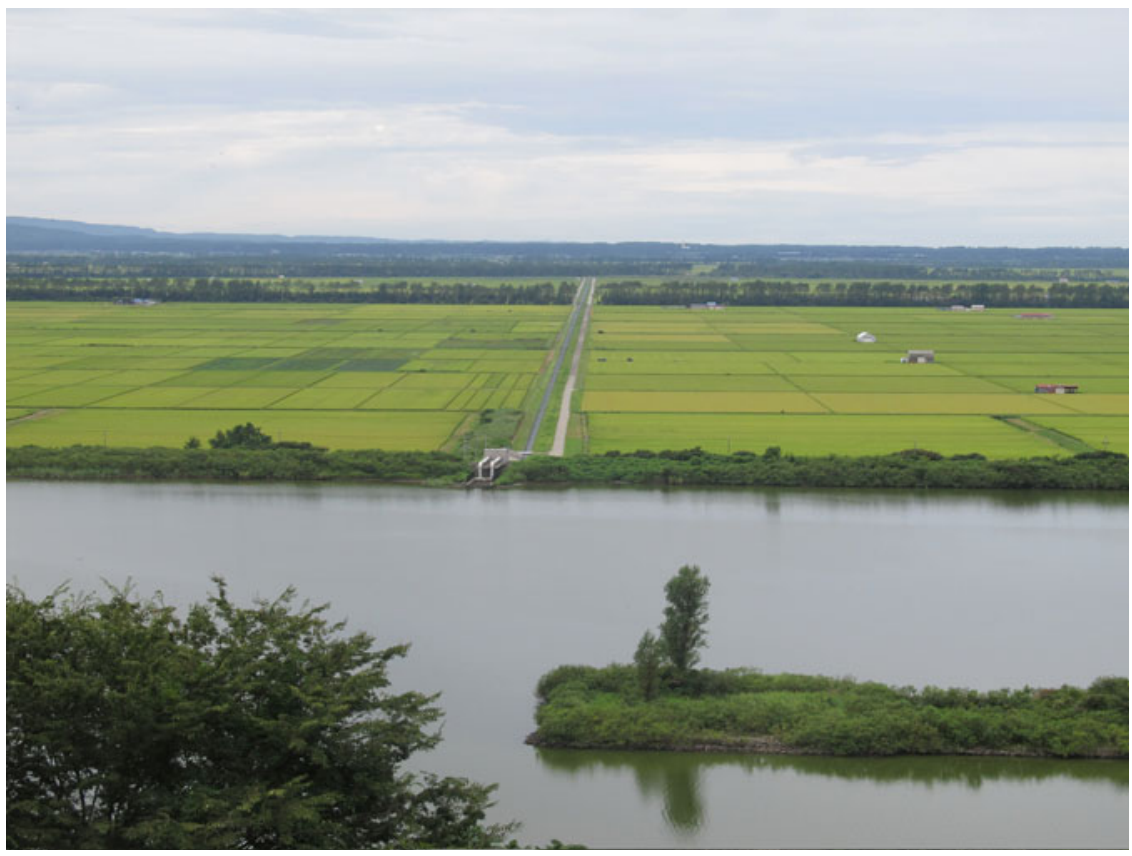

Fig. 2 Hachirogata central polder. A pomp station and drainage is in the center of the photograph (Photo by Yasunori Kitao); released under a Creative Commons Attribution-NonCommercialNoDerivatives 4.0 International License

Hachirogata polder was completed by draining some of the water, the lagoon was the second largest in Japan. The total area of the lagoon was about 22,000 ha, and measured $12 \mathrm{~km}$ from east to west, and $27 \mathrm{~km}$ from north to south. The lake shore was $90 \mathrm{~km}$ around, the average water depth was $3.2 \mathrm{~m}$, and the maximum depth was about $4.5 \mathrm{~m}$ (General Affairs and Planning Section of the Ogata Mura Village Office 2011). The aim in constructing the polder was to create 17,000 ha of arable land, including coastal polders (Jansen 1954); it was the largest polder project in the modern period of Japan. It was started by the Ministry of Agriculture and Forestry (MAF) in 1952 as a research project. Construction eventually began in 1958, and the last piece of the project, the settlement on the polder, was completed in 1977. Over this period, the plan for this polder and its village changed many times, but after discussing it for around 25 years, the state finally completed the modern polder (Kitao 2008).

In the early 1930s, the Hachirogata lagoon was known as the "Lake of Death," because fishermen's livelihoods had deteriorated markedly due to the bad catch in 1932 (Akita Sakigake Shimpo 1935-5-30). Many local fishermen went to work as migrant workers in the Sea of Okhotsk fishing industry in order to earn a living, and other fishermen became farmers. Some lakeside villages began public construc- 


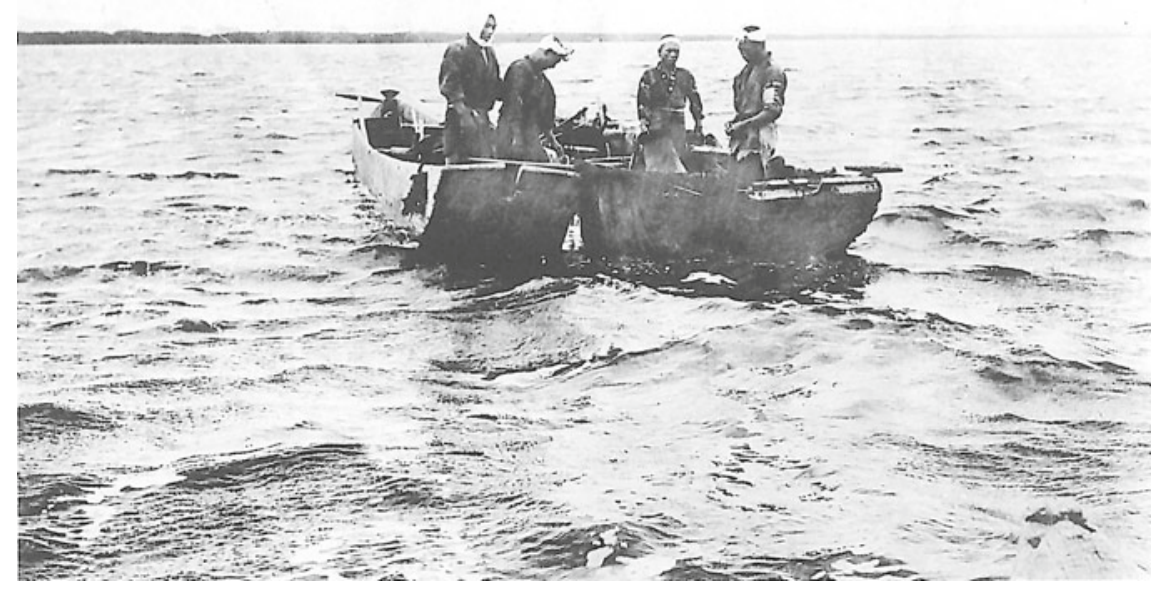

Fig. 3 Fisherman in the Hachirogata lagoon at the beginning of twentieth century. A specific point of the fishing boat is that the boat's bottom is flat because of the shallow water of the lagoon. Source The Fisheries Experiment Station of Akita prefecture, "The report on the using the water area of the Hachirogata Lagoon; 八郎潟水面利用調査昱告書,” Akita Prefecture, 1916; released under a Creative Commons Attribution-NonCommercial-NoDerivatives 4.0 International License

tion projects, reclaiming the lagoon to allocate the reclaimed arable lands to these fishermen/farmers (Akita Sakigake Shimpo 1935-5-31).

The fishermen thought that the reasons for the bad catch were overfishing and damage by agricultural land expansion to the shallow lake bed that fostered the young fish. They also pointed to the reclamation of the estuary of the lagoon, noting that it prevented the free movement of fish from the sea to the lagoon (Akita Sakigake Shimpo 1935-5-30). Lawmakers of the Prefectural Council and fishermen's associations asked the Akita Prefecture Office (APO) to construct a fish way at the estuary of the lagoon, to give the fish a way to get around the barrier (Akita Sakigake Shimpo 1936-9-8). The fishermen asked the APO to take measures to prevent illegal poaching, to control lake bank reclamation projects, and to promote the fishery as an industrial reinforcement policy. (Akita Sakigake Shimpo Newspaper 1935-5-30). The fishermen were seeking to preserve their way of life on the shores of the lagoon (Akita Sakigake Shimpo 1937-2-5), which depended on the brackish ecosystem. In response, the APO began studying the fostering of the fish, and indicated that they would permit only a minimum of landfill construction projects which would not affect the fishery; ultimately, it promised to promote fishery as a policy (Akita Sakigake Shimpo 1935-6-21). 


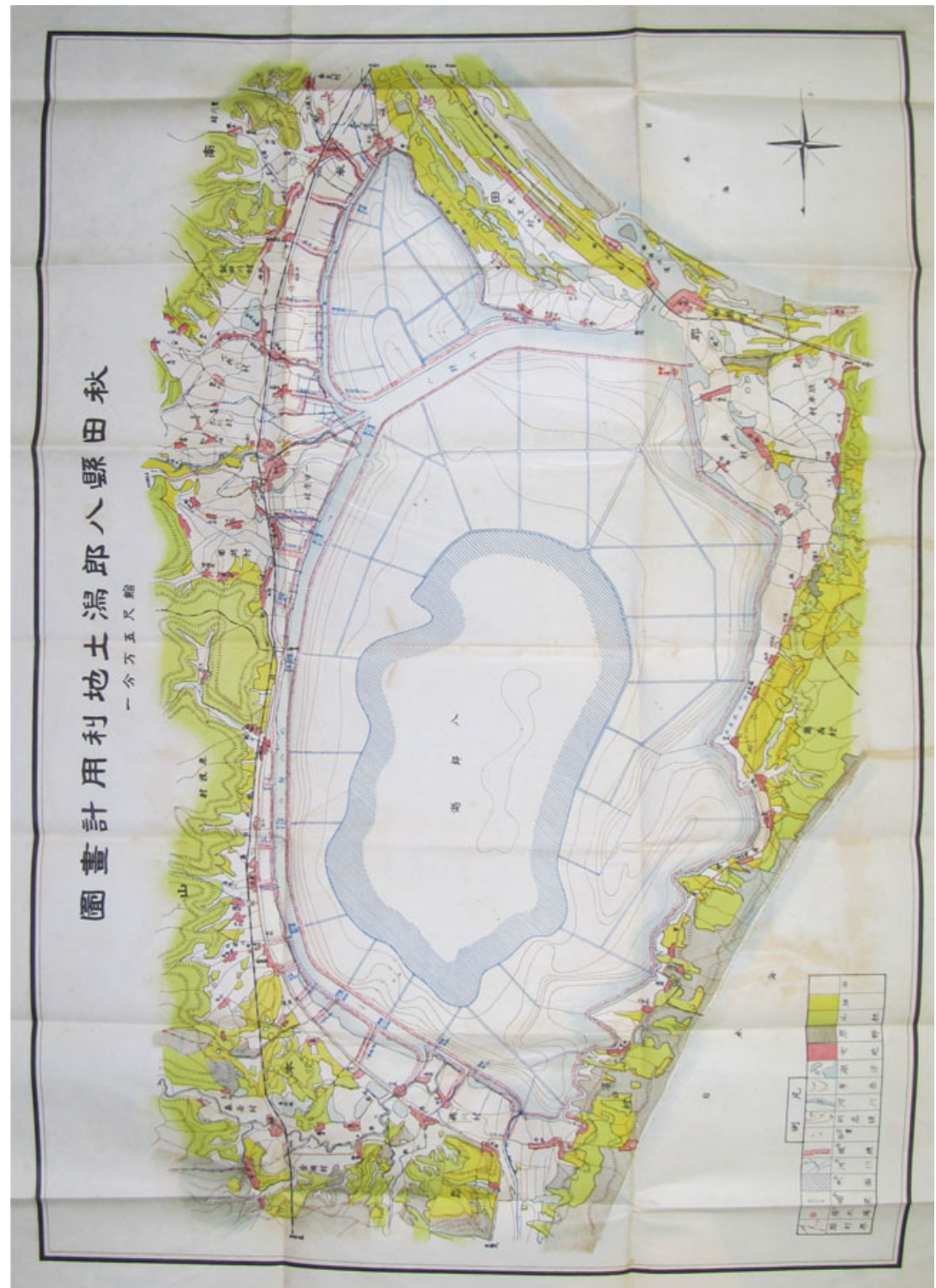

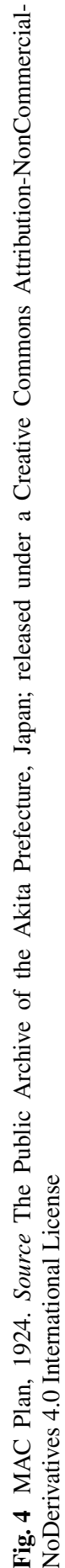




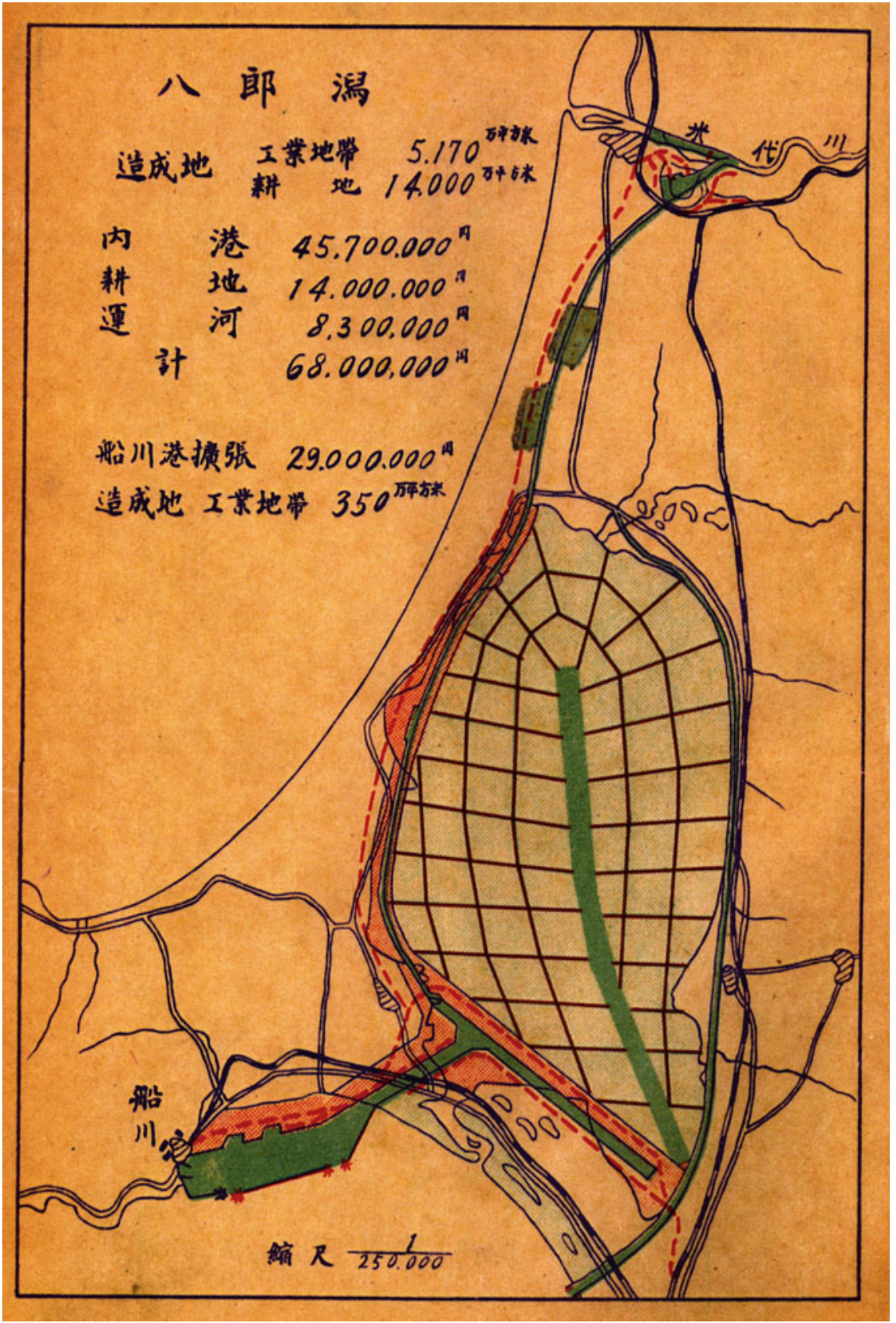

Fig. 5 MHA Wartime Plan, 1940. Source Akita Prefectural Library;"The Greater East Asia CoProsperity Sphere and Hachirogata; 大東平建設と八郎鼬”; released under a Creative Commons Attribution-NonCommercial-NoDerivatives 4.0 International License 


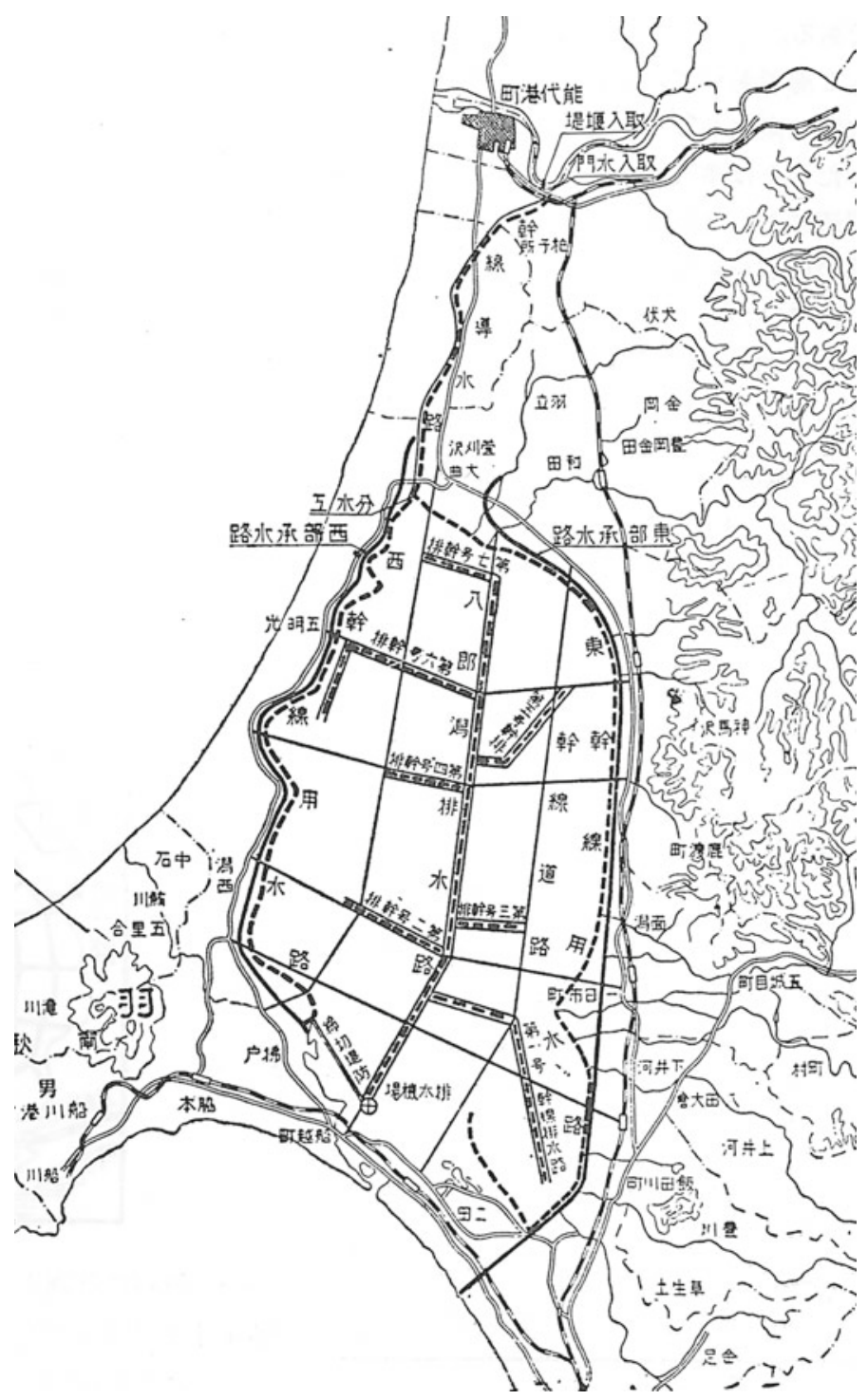

Fig. 6 MAF Wartime Plan, 1941. Source The Institute of National Development Projects; 国土開発調査会; “Developing the Hachirogata Lagoon;拓けゆく八郎潟”, 1960, p 24; released under a Creative Commons Attribution-NonCommercial-NoDerivatives 4.0 International License 


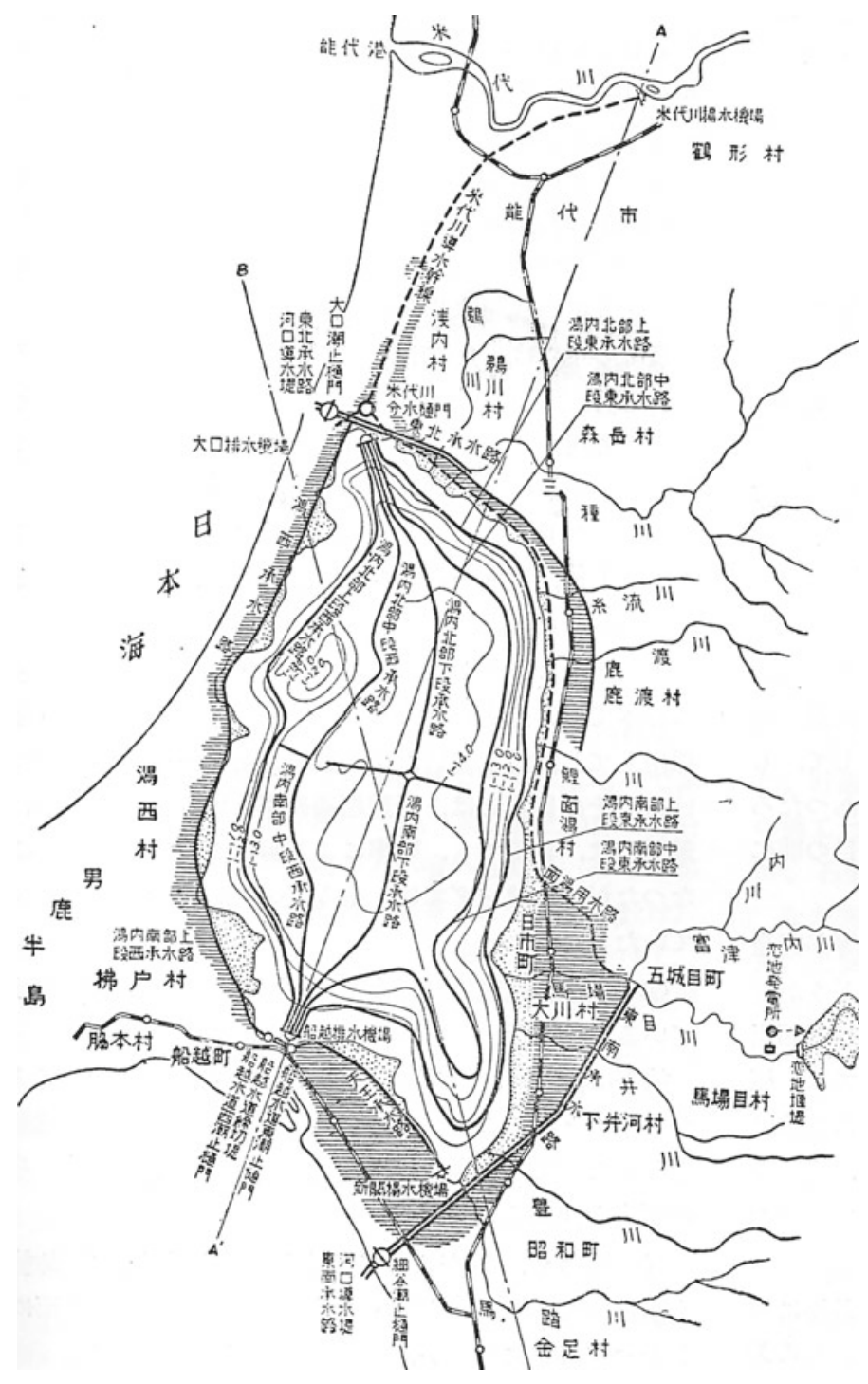

Fig. 7 MAF Post-Wartime Plan, 1948. Source The Institute of National Development Projects; 国土開発調查会;“Developing the Hachirogata Lagoon;拓けゆく八郎潟”, 1960, p 25); released under a Creative Commons Attribution-NonCommercial-NoDerivatives 4.0 International License 
Aggressive government intervention in lagoon planning began under the wartime regime in the early 1930s. The Ministry of Agriculture and Forestry (MAF) questioned the effect of opening a fishway in the estuary, but the Ministry of Home Affairs (MHA), like the fishermen, was interested in creating one (Akita Sakigake Shimpo 1938-9-23). In 1939, the APO and MAF began considering creating 18,000 ha of agricultural land by dividing the land reclamation into three phases (Akita Sakigake Shimpo 1939-4-23). The MAF conducted a survey, but they did not take the fishery resources into consideration (Akita Sakigake Shimpo 1939-4-23); this time, the MHA did not express an interest in opening a fish way either. Instead, it proposed plans for developing a canal, factory areas, and port facilities along with the full reclamation of the land (Kanamori 1940a, b). This plan became a national plan for an industrial area, and also a national project for increasing food production during wartime. The MHA and MAF both proposed full reclamation, turning the entire lagoon into agricultural land. But they had different motivations: the draft plan of the MHA aimed to promote world trade, contrasting with the MAF plan for activating the economy of the region (Figs. 4, 5, 6 and 7).

After the outbreak of the Pacific War, the MAF conducted a survey for the project, but did not actually start construction due to a lack of materials and manpower (Morooka 1960a, b). The government emphasized the importance of the fishing resources of the lagoon to the war effort (Akita Sakigake Shimpo 1941-1210). A Navy officer acknowledged the necessity of building port facilities in the Bay of Akita, but he said that land reclamation was unnecessary (Akita Sakigake Shimpo 1942-4-18). The following issues related to rivers were also being discussed under the wartime regime: building flood countermeasures (Sawa 1937); reducing the civil engineering budgets of local municipalities (The Japan River Association 1939); effectively using water resources (Mizutani 1940); and handling fishery rights (Tokusaki 1938). The various parties debated priorities. Considering the maintenance costs such as the revetment of rivers, one opinion was that building flood countermeasures was more important than increasing food production (Horikiri 1942). Another was that it was better to play a role in the war by using the water resources of the lagoon for fishing rather than to reclaim its land for agricultural land development or industrial land construction.

Before the war, the government had been decreasing rice production, having already neglected domestic agricultural production (United Nations 1955). Immediately, after losing the war (1945), the government had to tackle the food problem, and the project for the lagoon was the strongest candidate for developing arable lands (Akita Sakigake Shimpo 1945-8-26). The MAF proposed an impoldering plan in 1945 , to build 18,500 ha of arable lands for the returnees from the former colonies and from battlefields in Asia and the Pacific Ocean who did not have any productive lands or jobs. At that time, the government expected fishery and agriculture to coexist (Akita Sakigake Shimpo 1945-10-19), but it was not clear how. In order to resolve this issue, the APO held a meeting in which staffs of the prefecture were able to propose their ideas. One suggestion was building a partial polder, and another was prohibiting any construction projects in the lagoon that would damage the fishery. 
The president then presented to the MAF the APO's internal decision that there would not be any reclamation work in the lagoon (Akita Sakigake Shimpo 1946-3-13).

The prefecture and the national government had refrained from disagreeing during the war, but now, opposing to the APO's decision, the government technocrats insisted on a full reclamation plan. Their opinion had not changed; if anything, it was even stronger.

\section{Coexistence of Fishery and Agriculture}

After the war, the lagoon development project was back on the table, with the goal of increasing food production and facilitating the population increase of the whole country. Japan had regained independence politically, but self-sufficiency in food required economic independence. The government and local municipalities laid plans to develop new agricultural settlements throughout the whole country, and they expected 5000 farming families to settle in the Hachirogata polder (Akita Sakigake Shimpo 1955-10-26). The MAF completed a reclamation plan in 1948 (the post-war MAF Plan) that proposed 10,250 ha of reclaimed land, and assumed that 5500 new families would settle on it. This number included 3250 local families (including fishermen) (Morooka 1955). This post-war plan was not intended to actually allocate farmland to local residents, but it does express the government's intention of expanding farmland throughout the country (Akita Sakigake Shimpo 1953-8-18). The MAF published a full reclamation plan as a comprehensive development plan in September 1951 (Akita Sakigake Shimpo 1951-9-10). But the Economic Stability Headquarters of the government requested that it carry out reclamation projects only with the consent of the local fishermen (Akita Sakigake Shimpo 1952-8-29). (Akita Sakigake Shimpo 1952-4-27 \& 1952-8-14).

In response, the vice president of Akita Prefecture announced that if there were a sound scientific basis and financial support, the prefecture would accept a project for the construction of a polder of around 3000 ha (Akita Sakigake Shimpo 19528-29). With the attitude of APO clear, the MAF were able to establish a research office to investigate the impact of the polder project on the local fishermen (Akita Sakigake Shimpo 1953-1-4). Akita Prefecture established an experimental fishery station in the south part of the lagoon (Akita Sakigake Shimpo 1953-5-13). Thus, the government and Akita Prefecture showed concrete consideration to fishermen as things progressed. Indeed, to preserve a stable social situation for building the polder, it was necessary to set up a democratic development process that gave due consideration to the protection of the fishermen's living rights and coordinated fishing and agriculture.

Local residents organized the Hachirogata Development Council, but the fishery groups on the council still opposed the reclamation plan. They said that the political view of Akita Prefecture regarding the fishery had not been consistent and the prefecture had not done enough to satisfy their request for a crackdown on illegal fishing, or constructed the fishway at the estuary that they had been requesting since 
the 1930s. The fishermen still distrusted the APO as much as they had before the war (Akita Sakigake Shimpo 1953-5-28) (Akita Sakigake Shimpo 1953-8-18). The development plan for the lagoon could not go forward.

To overcome the impasse, the MAF proposed that the fishermen become farmers of the arable lands in the future polder, and the APO prepared to organize a consultation body to integrate the local opinions (Akita Sakigake Shimpo 1953-7-28). Meanwhile, in August 1953, the government took steps toward creating that arable land. In a cabinet meeting, then Prime Minister Shigeru Yoshida announced a project that introduced Dutch reclamation technology to Japan (Akita Sakigake Shimpo 1953-81). Masao Koga, a technocrat of the MAF, went to the Netherlands in 1953 in order to invite Dutch engineers to assist in the polder project. (Morooka 1960a, b) the Dutch Government sent him to Professor Jansen of Delft University of Technology, an expert in the field of land reclamation. Jansen came to Japan in April 1954 and submitted a report to the Japanese Government in August 1954 (Hachiro-Gata Reclamation Bureau, 1969).

Jansen proposed a compromise between the MAC Plan (1920s) and the MAF Wartime Plan: a water area in the southern part of the lagoon, connected to the sea through a sluice gate in the estuary, and a polder in the north, constructed with the technology of the Dutch IJsselmeerpolders in the Netherlands. That is, Jansen actively insisted on a middle way. Akita Prefecture and the local municipalities immediately approved the Jansen proposal (Akita Sakigake Shimpo 1954-8-3). In

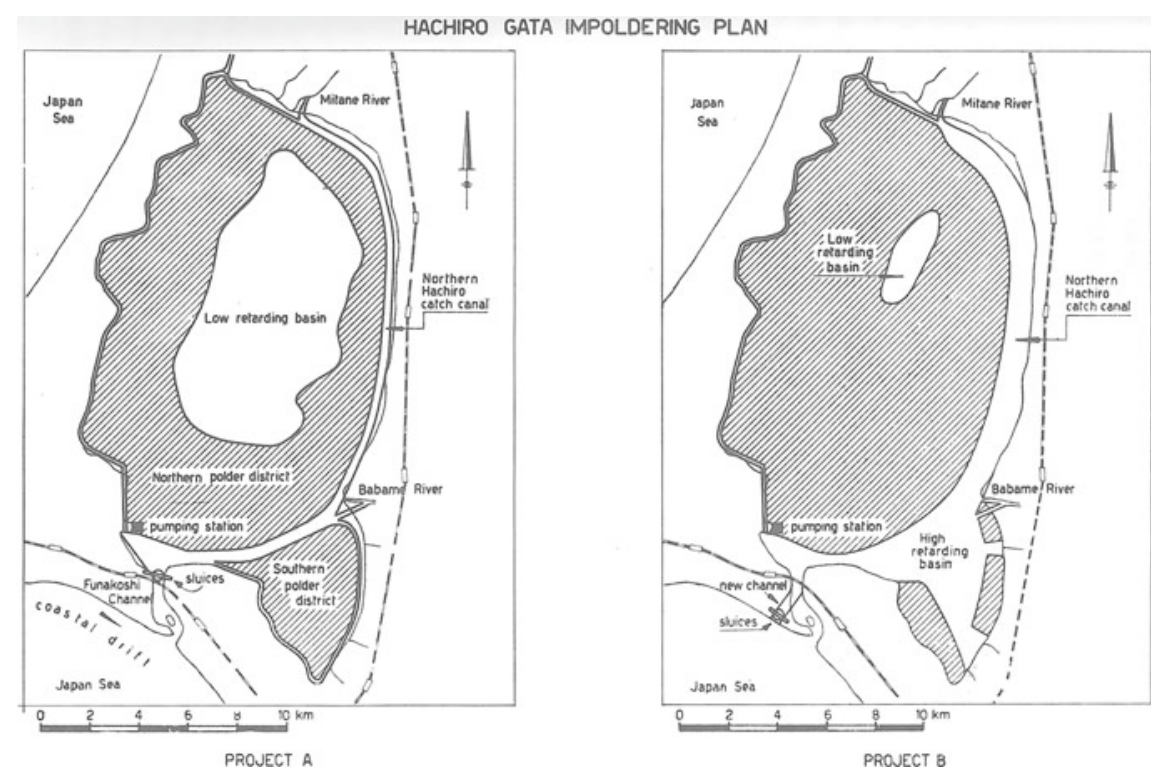

Fig. 8 Two types of polder in the lagoon, proposed by Prof. Jansen in 1954. Source Jansen "Some Remarks on Impoldering in Japan," The Ministry of Agriculture \& Forestry 1954, p.6; released under a Creative Commons Attribution-NonCommercial-NoDerivatives 4.0 International License 


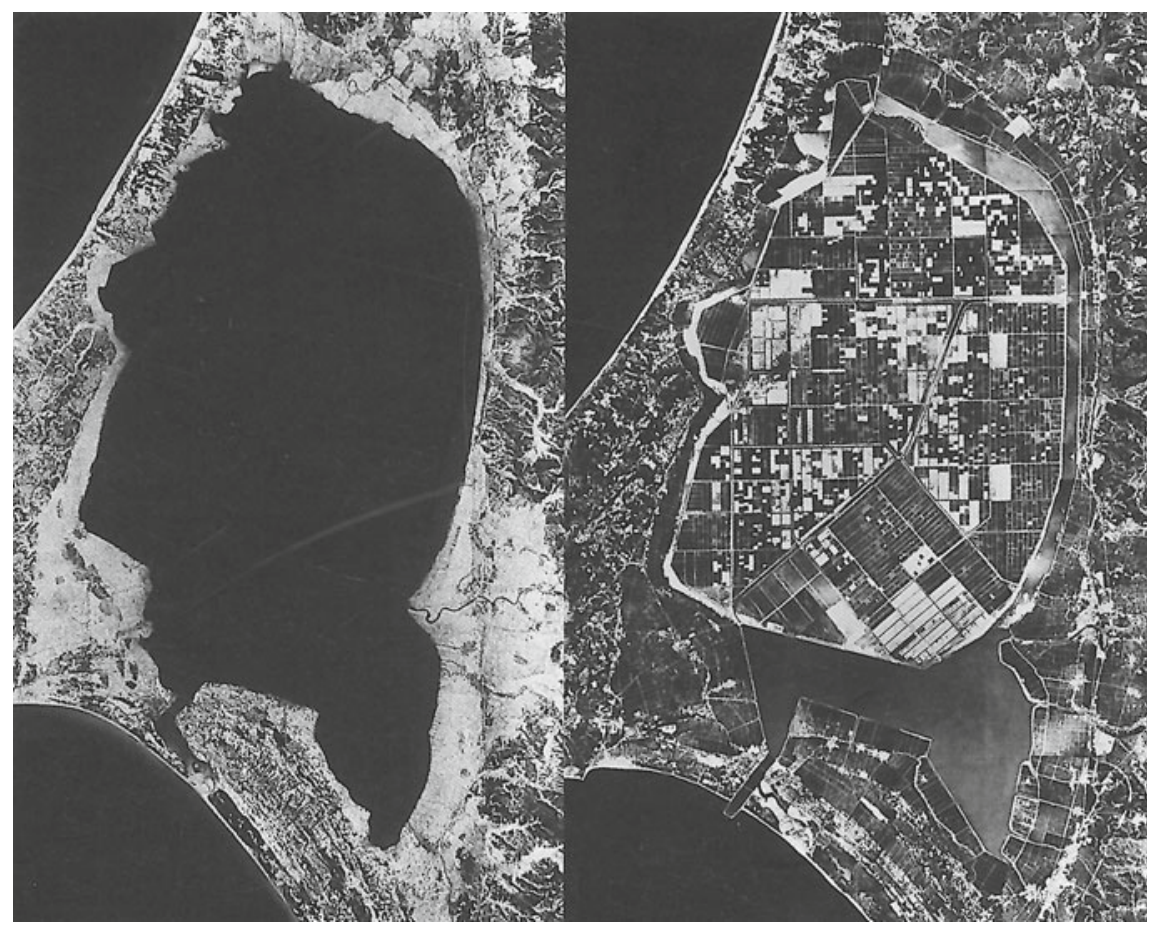

Fig. 9 Comparing the Hachirogata Lagoon before and after (Aerial photos). Source General Affairs and Planning Section of the Ogata Mura Village Office; 大潟村役場総務企画課(編) A History of the Rural Development Projects of the Ogatamura Village in the Hachirogata Central Polder;八郎潟中央干拓地「大潟村」における農村集落の建設と村づくりの变逻, 2011, p 7); released under a Creative Commons Attribution-NonCommercial-NoDerivatives 4.0 International License

addition, local youth associations and women's associations expressed their approval (Akita Sakigake Shimpo 1954-8-23).

The fishermen balked because of the sluice gate. Jansen put it to prevent flood damage and separate the remaining lake from the sea to secure fresh water for the polder (Jansen Pr 1954). But the proposal was introduced in the local newspaper as a possible plan for sustaining the fishery: The map in the newspaper does not show a sluice gate, and readers might well have understood and expected that the Jansen plan would not change the connection between the lagoon and the sea. When the fishermen found out about the water gate, they opposed the Jansen proposal: it was clear to them that it would devastate the fishery. They insisted that landfilling, not draining the lagoon, be the central engine of reclamation work (Akita Sakigake Shimpo 1954-8-3).

The APO had already explained that the fishery would continue with the fishery experimental station in the remaining part of the lagoon (Akita Sakigake Shimpo 1954-5-22). But both the plan and the explanations indirectly indicated that the 


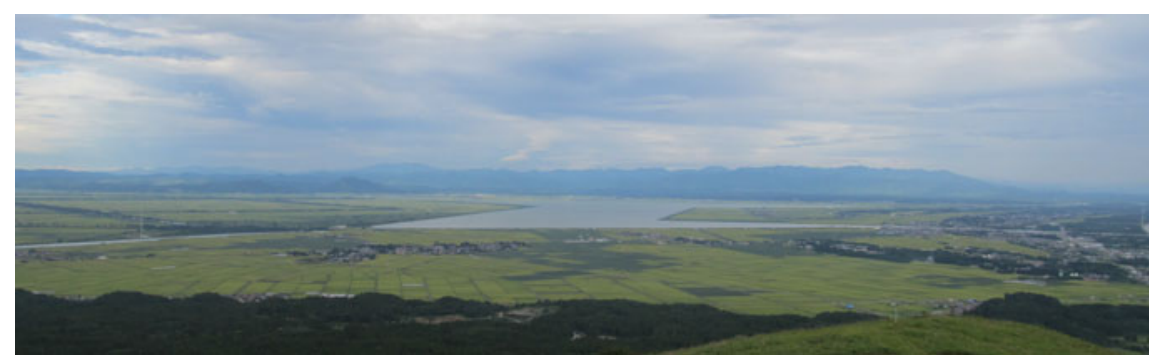

Fig. 10 Landscape of the Hachirogata region, seen from the Kanpusan Mountain. Left: the Hachirogata central polder. Middle: the remaining lake. Right: the villages and paddy field around the lagoon (Photo by Yasunori Kitao); released under a Creative Commons AttributionNonCommercial-NoDerivatives 4.0 International License

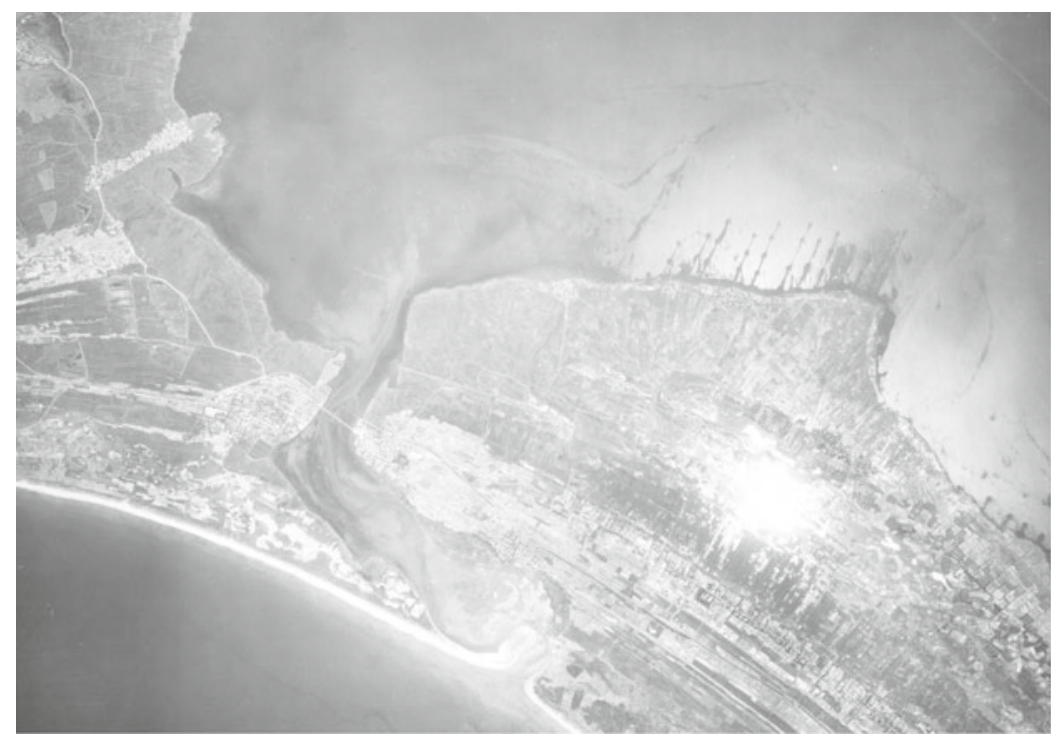

Fig. 11 Estuary of the Hachirogata lagoon before the impoldering project, 1949 (Aerial photo). Source The Geographical Survey Institute of Japan, Funagawa, USA-M1111-35: https://mapps. gsi.go.jp/maplibSearch.do\#1. Last retrieved on the August 15, 2017; released under a Creative Commons Attribution-NonCommercial-NoDerivatives 4.0 International License

future fishery would be a fresh water lake. The fishermen were trying to find a way to reclaim the lands by landfilling at the final stage of the planning of the central polder because they hoped to find a tiny chance to continue their traditional fishing in the brackish lake of Hachirogata lagoon. Opposition to the reclamation project from a standpoint dependent on keeping the brackish water means that it insisted on the natural conservation of the brackish lake.

Nonetheless, the Jansen compromise triggered a debate which led to breaking the fisherman's solidarity. Wealthy fishermen with powered vessels continued to oppose 


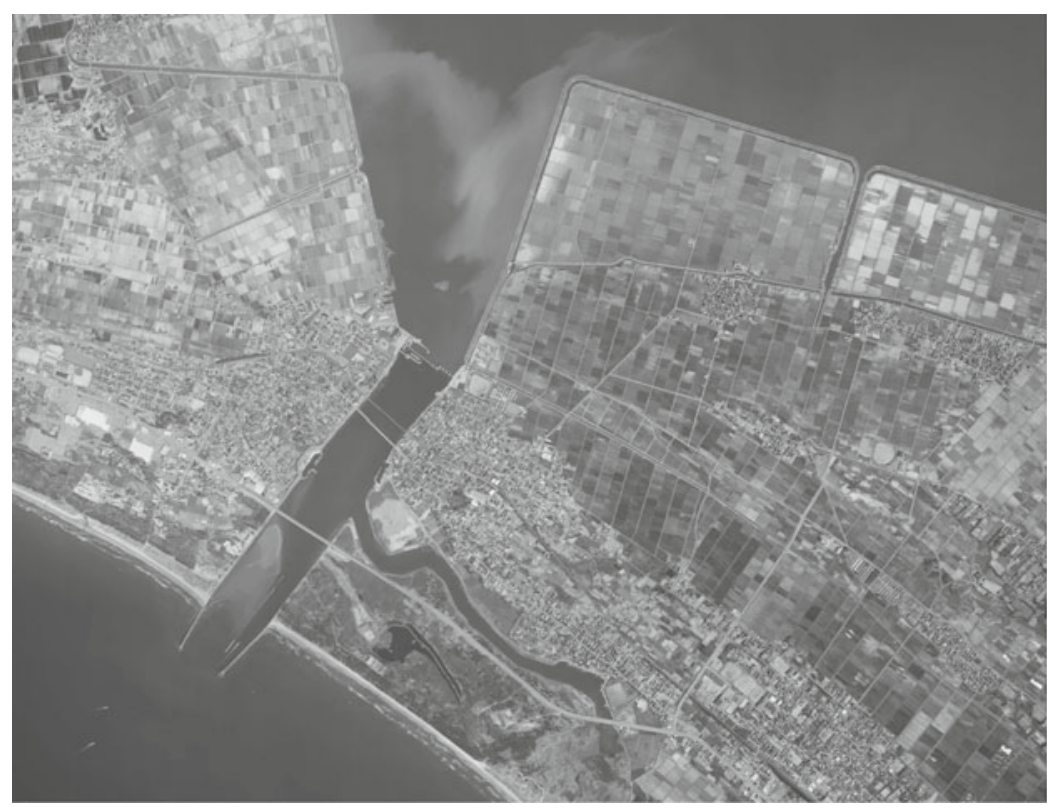

Fig. 12 Estuary of the Hachirogata lagoon after the impoldering project, 2004 (Aerial photo). Source The Geographical Survey Institute of Japan, Akita,MTO20046X: https://mapps.gsi.go.jp/ maplibSearch.do\#1 (Last retrieved on the 15th August 2017); released under a Creative Commons Attribution-NonCommercial-NoDerivatives 4.0 International License

full reclamation. The smaller fisherman who began to understand the limitations of the capacity of the fishing catch in the brackish water had to decide whether to withdraw from the lagoon, and many came to believe that their livelihood would be stabilized by agriculture in the polder (Akita Sakigake Shimpo 1954-8-11). The brackish water disappeared with construction of the polder and the freshwater lake, which ultimately halted the opposition movement by the fishermen (Figs. 8 and 9).

In the end, however, versions of both fishery and agriculture continued at Hirochigata, a way forward made possible by the plan of 1955, drafted by the MAF based on the proposal by Jansen. In this plan, a total of 699 immigrant families were to be settled on 13,289 ha of the polder, and 7245 units of "allocated increased arable lands" (Zoutan in Japanese) are detailed (Morooka 1955). In the same year, the APO made provision for 5000 immigrant families to settle on 13,000 ha of the arable land (The Governor Office of the Akita Prefecture 1956). It can be seen by comparing the number of settlers that the APO plan addressed national policy, while the MAF plan was regionally friendly. The government and prefecture were trying to surmise each other's wishes and to act with consideration for each other's situation, a strategy known as "sontaku." (Unfortunately, sontaku has come to mean pandering to someone in a position of authority.) The plans can be regarded as a mutually beneficial bureaucratic strategy, and they became the basis of a solution for the discrepancies 


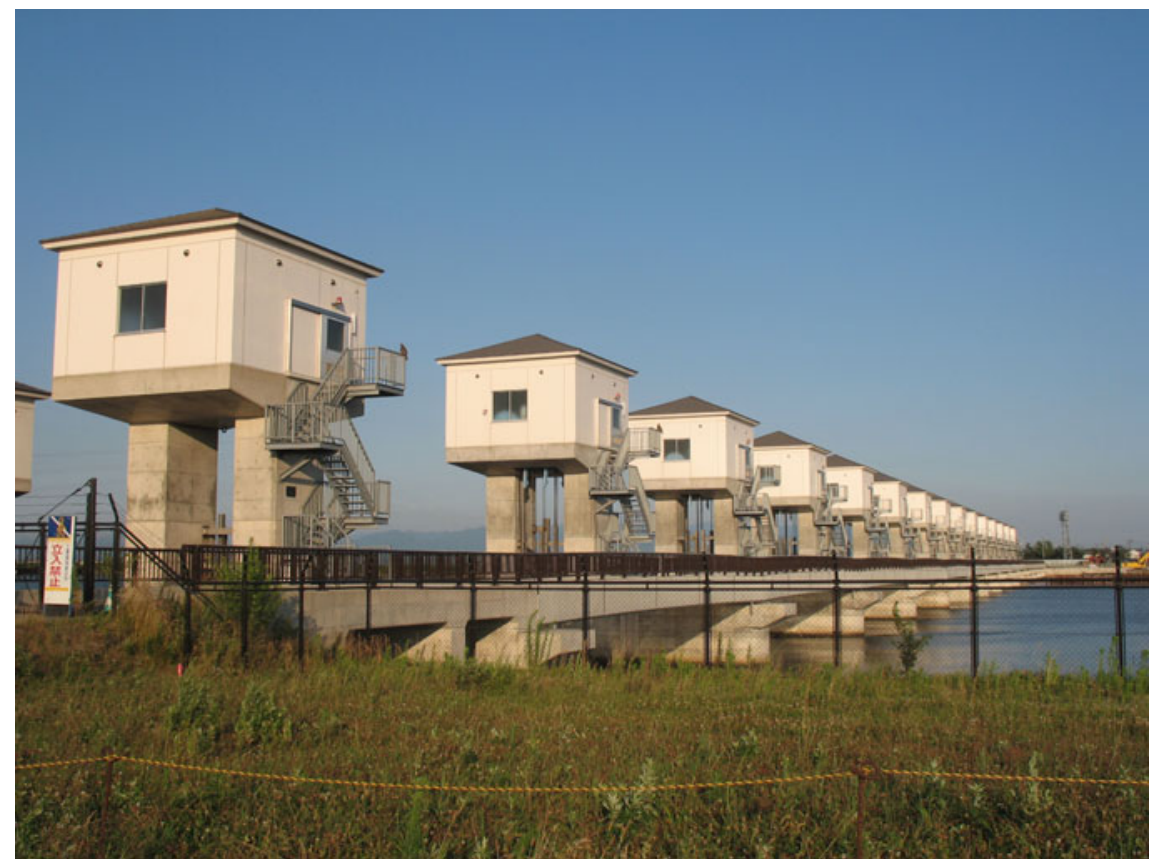

Fig. 13 Tide sluices of the Hachirogata lagoon. These tide sluices were built in 1961. This changed the remaining lake into a fresh water lake (Photo by Yasunori Kitao); released under a Creative Commons Attribution-Non Commercial-No Derivatives 4.0 International License

between fishing and agriculture in the administrative and regional planning of the Hachirogata development (Figs. 10, 11, 12 and 13).

\section{Conclusion}

Today, one aspect of the history of the Hachirogata lagoon has become its entire cultural heritage: Japanese scholars and museums celebrate the land reclamation as a signal achievement, emphasizing physical size, national investment, and technological innovation. Moreover, stories of the promise of the new land, and the future of the people living and working there, all form a kind of positive propaganda. Politically and socially, it has been better to forget the rest of the history, particularly the struggle with the historical past and local fishing traditions.

However, in reassessing the heritage of Hachirogata polder and its region, it is important to see the long debate over how best to use lake and the fishery, and to recognize the finding of a balance of the different viewpoints-between the lake and the polder, fishery and agriculture, traditional and modern — as a historic sociocultural planning achievement. The fishermen's protests ensured that the process 
included all stakeholders, a message of this heritage that might inform planning going forward. Finally, heritage debates can take this heritage of balance as a model for thinking about narrating history more fully; and planners and politicians can take it as a model for resolving future conflicts over land use during climate change and the shortage of natural resources on the earth.

Acknowledgements This work was supported by JSPS KAKENHI Grant Number 16H02386.

\section{References}

General Affairs and Planning Section (ed) (2011) 大潟村役場総務企画課(編), “八郎潟中央干拓地「大鼬村」における農村集落の建設と村づくりの变遷; A history of the Rural Development Projects of the Ogatamura Village in the Hachirogata Central Polder, The Village Office of Ogatamura, p,3, pp. 38-41

Hachiro-Gata Reclamation Bureau (ed) (1969) The history of reclamation project of Hachiro-Gata; 八郎潟干拓事業誌, p 11

Heuvel D, van den Heuvel D, Mesman M, Quist W (eds) (2008) The challenge of change: dealing with the legacy of the modern movement. Delft University Press, Delft

Horikiri Z (1942) 堀切善次郎, “治水の急務[Emergency on Flood Control, 河川[The Rivers] Vol. 1, No.4, The Japan River Association, pp 9-10

Jansen $\operatorname{Pr}(1954)$ Some remarks on impoldering in Japan, The Ministry of Agriculture \& Forestry, p 5, pp 40-41, p 46

Kanamori M (1940) 金森誠之, "National Planning and Development Project of the Hachirogata Lagoon; 国土計画と八郎潟開発;”, Civil Division at Akita Prefecture

Kanamori M (1940) 金森誠之, The greater East Asia Co-Prosperity Sphere and Hachirogata; 大東井建設と八郎潟, The Ministry of Home Affairs of Japanese Government 1940

Kitao Y (2008) The modern agriculture village on the Hachirogata-Polder in Japan: the design process during the economic development period. In: 10th international conference of Docomomo, the Netherlands, pp 449-451

Ministry of Agriculture and Commerce (MAC) (1914) 和蘭における耕地拡張大計; The great planning of expanding Arable lands in the Netherlands, Ministry of Agriculture and Commerce, Japanese Goverenment 1914

Miyata M et al. (2012) 宮田正馗, 他, “ゼロからの自治 大潟村の軌跡と村長・宮田正馗; Self-government: a history of Ogata Mura village and the Mayer Miyata, Kojinsha Publishing; 公人社 2012

Mizutani S (1940) 水谷 䥞, Evocating water resources for productions; 水資源の生産力喚起”, Hydro Civil Eng 水利と土木, The Japan River Association, 13(7):2-7

Morooka M (1960a) Memories of the Hachirogata Lagoon; 八郎鼬干拓の思い出”, The Magazine of National Development; 国土開発, 9(5):40

Morooka M (1955) 師闺政夫, About the planning of the Hachirogata Polder; 八郎潟干拓計画に就いて”, Tohokukenkyu; 東北研究, 5(6):14-21, 40-41

Morooka M (1960b) 諸岡政夫, Memory on the impoldering project of the Hachirogata Polder; 八郎潟干拓の思い出, Developing the Hachirogata Lagoon; 拓けゆく八郎潟, The Institute of National Development Projects; 国土開発調査会, p 40, p 62

Sawa S (1937) 澤 重民, A study on flood disaster;水害に関する若干の考察”, Hydro Civil Eng; 水利と土木, The Japan River Association 11(12):2-7

Tahara J (1942) 田原二郎, A report on the releasing fish into the rivers; 河川工作物に対する魚族放流事業の概況, Hydro Civil Eng; 水利と土木, 1(5):12-15 
The Fisheries Experiment Station of Akita Prefecture (1916) "The Report on Using the Water Area of the Hachirogata Lagoon; 八郎鼬水面利用調査昱告書”, Akita Prefecture, 1916

The Governor Office of the Akita Prefecture (ed) (1956) 秋田県知事室広昱係 (編), “八郎潟干拓:米の增産50万石世紀の大事業; Impoldering project of the Hachirogata Lagoon-large scale rice production project in the 20th Century”,秋田県八郎鼬干拓推進委員会; The Promotion Committee of Impoldering Project of the Hachirogata Lagoon 1956

The Japan River Association (1939) Civil Engineering in the War Footing;戦時下に打け0る土木事業(foreword), Hydro Civil Eng; 水利と土木, 12(1):4

Tokusaki K (1938) 徳埼 香, An discussion on expropriation on fishery right; 漁業権の収用について, Hydro Civil Eng; 水利と土木, The Japan River Association, 10(12):35-40

United Nations (1955) Economic commission for Asia and the Far East, "Water resource development in Ceylon, China: Taiwan, Japan and the Philippines", United Nations, 1955, p 70

\section{Local Newspaper}

Akita Sakigake Shimpo Newspaper, 1935-5-30 (八郎湖埋立やめて貪いたい;Stop the Reclamation Project in the Hachirogata Polder)

Akita Sakigake Shimpo Newspaper, 1935-5-31 (濱口村が村営で八郎湖の埋立開㧞; The Hamaguchi Mura Village starts reclamation project in the Hachirogata Polder)

Akita Sakigake Shimpo Newspaper, 1935-10-23 (開墾か停止; Stop or Start of the Reclamation)

Akita Sakigake Shimpo Newspaper, 1935-6-21 (部課長会議の申合せ事項;The Meeting of the Bureaucrat of the Akita Prefecture Office)

Akita Sakigake Shimpo Newspaper, 1936-9-8 (Promotion Movement for the Babame-kawa River improvement)

Akita Sakigake Shimpo Newspaper, 1937-2-5 (魚族繁殖計画と共に一部を干拓;A reclamation project in the Hachirogata lagoon together with the fishery promotion planning)

Akita Sakigake Shimpo Newspaper, 1938-9-23 (八郎湖魚道改修;An Improvement Plan for the fish-way in the ensure of the Hachirogata lagoon)

Akita Sakigake Shimpo Newspaper, 1939-4-23 (An improvement plan for the fishway in the estuary of the Hachirogata lagoon)

Akita Sakigake Shimpo Newspaper, 1939-4-23 (調查に来る農林省も大乗気; The MAF comes to the Hachirogata lagoon for research)

Akita Sakigake Shimpo Newspaper, 1941-12-10 (宝庫八郎鼬の開発;The Development project of the Hachirogata lagoon, the treasure)

Akita Sakigake Shimpo Newspaper, 1942-4-18 (第一に港の完成八郎潟は潰すな; Building the port is important, but do not develop Hachirogata lagoon)

Akita Sakigake Shimpo Newspaper, 1945-8-26 (土木事業の今後;Land development project in the near future)

Akita Sakigake Shimpo Newspaper, 1945-10-19 (八郎潟の干拓;Impoldering project of the Hachirogata lagoon)

Akita Sakigake Shimpo Newspaper, 1946-3-13 (八郎潟干拓反対決議; The decision on the objection for the reclamation project of the Hachirogata lagoon)

Akita Sakigake Shimpo Newspaper, 1951-9-10 (八郎潟の干拓へ;Toward the development project of the Hachirogata lagoon)

Akita Sakigake Shimpo Newspaper, 1952-4-27 (八郎潟振興調查費;The budget for the economy promotion research on the Hachirogata lagoon)

Akita Sakigake Shimpo Newspaper, 1952-8-29 (農林省4案示す;The MAF proposed four projects) 
Akita Sakigake Shimpo Newspaper, 1952-8-14 (Investigation on the possibility of the reclamation project)

Akita Sakigake Shimpo Newspaper, 1953-1-4 (結論を今年中に;Conclusion would be made in this year)

Akita Sakigake Shimpo Newspaper, $1953-5-13$ (The biggest fish farm in the Tohoku Region)

Akita Sakigake Shimpo Newspaper, $1953-5-28$ (県の方針ただす;Requesting for the APO)

Akita Sakigake Shimpo Newspaper, 1953-8-18 (八郎潟の利用開発;Using and Developing the Hachirogata Lagoon)

Akita Sakigake Shimpo Newspaper, 1953-7-28 (八郎潟開発同盟発足;Founding the alliance of the Hachirogata development project)

Akita Sakigake Shimpo Newspaper, 1953-8-1 (干拓事業を協力推進吉田首相から指示;Promoting the impoldering project with the support of the prime minister)

Akita Sakigake Shimpo Newspaper, 1954-5-22 (八郎潟干拓共同案なる;The Collaborative Plan for the impolderig project on the Hachirogata lagoon)

Akita Sakigake Shimpo Newspaper, 1954-8-3(漁民ヤ案に反対表明;Opposition against the Jansen Plan)

Akita Sakigake Shimpo Newspaper, 1954-8-23(全額融資は困難;The loan that covering total cost from the World Bank is not easy)

Akita Sakigake Shimpo Newspaper, 1954-8-11(ヤ案の干拓に賛成;Approval for the Jansen Plan)

Akita Sakigake Shimpo Newspaper, 1955-10-26 (八郎潟干拓を展望する;Viewing the reclamation project of the Hachirogata lagoon)

Yasunori Kitao is Professor at Kyoto Women's University, Japan, and he previously worked at the Kyoto Institute of Technology and Delft University of Technology. His books include Collaborative Urban Design (2005), Architecture of Ralph Erskin (2008), Urban Street Design \& Planning (2013) and The Architecture in Colombian Environment (2014). He currently works on heritage and the built environment that are at once social, cultural, and industrial.

Open Access This chapter is licensed under the terms of the Creative Commons AttributionNonCommercial-NoDerivatives 4.0 International License (http://creativecommons.org/licenses/bync-nd/4.0/), which permits any noncommercial use, sharing, distribution and reproduction in any medium or format, as long as you give appropriate credit to the original author(s) and the source, provide a link to the Creative Commons license and indicate if you modified the licensed material. You do not have permission under this license to share adapted material derived from this chapter or parts of it.

The images or other third party material in this chapter are included in the chapter's Creative Commons license, unless indicated otherwise in a credit line to the material. If material is not included in the chapter's Creative Commons license and your intended use is not permitted by statutory regulation or exceeds the permitted use, you will need to obtain permission directly from the copyright holder.

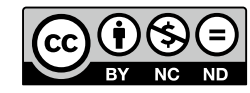

